\title{
KESESUAIAN TAMAN KOTA DI SURAKARTA BERDASARKAN KONSEP KOTA LAYAK ANAK
}

\author{
SEPTYANI WIDYASTUTI ${ }^{1}$ \\ PROGRAM STUDI PERENCANAAN WILAYAH DAN KOTA \\ FAKULTAS TEKNIK \\ UNIVERSITAS SEBELAS MARET SURAKARTA \\ EMAIL : SEPTYANIWIDYAS@GMAIL.COM \\ ANA HARDiana ${ }^{2}$ \\ PROGRAM STUDI PERENCANAAN WILAYAH DAN KoTA \\ FAKULTAS TEKNIK \\ UNIVERSITAS SEBELAS MARET, SURAKARTA \\ Rufia ANDisetyana PUTRI ${ }^{3}$ \\ PROGRAM STUdI PERENCANAAN WILAYAH DAN KOTA \\ FAKULTAS TEKNIK \\ UNIVERSITAS SEBELAS MARET, SURAKARTA
}

\begin{abstract}
Surakarta is one of a city in Indonesia which has chosen for developing as child friendly city. Child friendly city is the concepts of a city which ensure the rights of children. The rights of children include express their opinion on the city they want, participate in social life, receive basic service (health and education), drink safe water and have acces to proper sanitation, be protection from exploitation, violence and abuse, walk safely in streets on their own, meet friends and play, have green spaces for plants and animals, live in unpolluted environment, participate in cultural and social events and be an equal citizen of their city. City park in Surakarta should suitable with child friendly city concept because city park is one of the green spaces that can be used to fulfill children play rights. The research question is to know the suitability of city park in Surakarta with the concept of child friendly city. There are five components for assessing this suitability: (1) accessibility, (2) recreation utility. (3) sport utility, (4) supporting facilities and (5) vegetation. The research method uses quantitive method with deductive approach and scoring analysis technique. The result shown that all of city park in Surakarta is not suitable with the criteria above. The conclusion of the research is Surakarta should increase the quantity and quality of whole components of city park based on the child friendly concept. Therefore, child friendly city in city park can be implementated and have the impact to guarantee the needs of children for playing in comfortable and safe park.
\end{abstract}

Keywords : Child Friendly City, Suitability, City Park

\section{PENDAHULUAN}

Kota adalah ruang bermukim masyarakat segala usia (Joga, 2013). Karena itu, harus mampu memenuhi hak masyarakatnya, tak terkecuali anakanak. Pemenuhan hak anak dapat dilakukan melalui penerapan konsep kota layak anak. Kota layak anak adalah konsep kota yang menjamin pemenuhan hak-hak anak, seperti hak pendidikan, kesehatan, perlindungan, non diskrimasi (UNICEF, 2016 dan Riggio, 2002). Penerapan konsep kota layak anak sangat diperlukan karena tahun 2012 sebanyak 51,5\% penduduk perkotaan adalah anak-anak. Tahun 2030, jumlah anak di perkotaan mencapai $80 \%$.

Pada tahun 2006 Indonesia mulai menerapkan konsep kota layak anak, dengan menunjuk 5 kabupaten/kota sebagai pilot project pengembangan $\mathrm{KLA}$, antara lain Kota Surakarta, Kota Jambi, Kabupaten Gorontalo, Kabupaten Sidoharjo dan Kabupaten Kutai (BAPERMAS, 2013). Salah satu peraturan yang mendukung pengembangan konsep KLA adalah 
Permen PP \& PA No 12/ 2011 tentang Indikator Kabupaten/Kota Layak Anak, berupa penguatan kelembagaan dan kluster hak anak.

Dalam Permen PP \& PA NO 12/2011, terdapat salah satu indikator terkait hak pendidikan, pemanfaatan waktu luang dan kegiatan budaya yaitu adanya fasilitas kreatif dan rekreatif ramah anak, diluar sekolah dan dapat diakses semua anak, dimana taman kota salah satu fasilitas rekreatif dan kreatif. Taman kota sebagai RTH untuk bermain dan berkreasi juga menjadi salah satu kualifikasi untuk menerapkan konsep kota layak anak (Subiyakto, 2012)

Ruang bermain yang sesuai dengan anak dilengkapi dengan fasilitas bermain segala usia, memiliki aksesibilitas yang mudah, terdapat vegetasi dan sebagai tempat berkumpul (Veitch et al, 2007). Oleh karena itu, taman kota sebagai ruang bermain harus dapat memenuhi kebutuhan akan fasilitas bermain untuk segala usia anak. Keberadaan taman kota di Solo penting karena ketersediaan taman dengan skala pelayanan dibawahnya kurang.

Permasalahan yang dihadapai oleh taman kota di Surakarta antara lain taman kota terletak di daerah ramai lalu lintas kurang dilengkapi fasilitas pendukung yang memudahkan anak untuk mencapainya. Kondisi taman di Surakarta kurang terawat karena banyak taman memiliki sampah yang berserakan, seperti taman P2KH Mojosongo.

Keberadaan fasilitas bermain pada taman kota juga sangat minim, sehingga dirasa kurang mampu memenuhi kebutuhan aktivitas bermain anak. Selain jumlah yang sedikit, keadaan fasilitas bermain juga kurang terawat karena banyak yang berkarat dan sudah rusak.

Melihat fakta-fakta di taman kota tersebut dapat dirumuskan pertanyaan penelitian "Bagaimana kesesuaian taman kota di Surakarta berdasarkan konsep kota layak anak?"

\section{TINJAUAN PUSTAKA}

\subsection{Konsep Kota Layak Anak}

Berdasarkan UNICEF (2004) definisi kota layak anak adalah kota yang melalui pemerintah lokalnya berkomitmen untuk memenuhi hak-hak anak, meliputi hak untuk memengaruhi keputusan tentang kotanya, menyatakan pendapatnya sesuai dengan kemauan dan kebutuhan mereka, berpartisipasi aktif dalam keluarga, komunitas dan masyarakat, memeroleh pelayanan dasar seperti kesehatan, pendidikan dan tempat tinggal, dapat mengonsumsi air yang aman dan mampu mengakses sanitasi yang layak, dilindungi dari eksploitasi, kekerasan dan perlakuan kejam, dapat berjalan dengan aman di jalan, bertemu teman dan bermain, memiliki ruang hijau dengan tumbuhan dan hewan didalamnya, tinggal dilingkungan yang bebas polusi, berpartisipasi di event atau kegiatan sosial dan budaya serta memeiliki hak yang sama untuk mengakses setiap pelayanan dasar, tanpa memerhatikan ras, agama, pendapatan, gender dan disabilitas. Salah satu kualifikasi yang harus dipenuhi oleh suatu kota dalam mewujudkan kota layak anak menurut Subiyakto (2012) adalah keberadaan ruang terbuka hijau seperti taman kota untuk tempat bermain dan berkreasi anak yang aman dan nyaman.

Dalam penyediaan ruang bermain harus didesign untuk anak-anak sehingga anak-anak mampu menjelajah lingkungannya dengan bebas, bertemu teman dan bermain (Riggio, 2002). Dalam perencanaannya anak diminta mengemukakan pendapatnya tentang fasilitas pendukung taman, tanaman (seperti keberadaan pohon besar, pohon kecil dan bunga di taman). dan fasilitas bermain (Omid et al, 2007). Salah satu cara yang dapat digunakan untuk mengetahui keinginan anak tentang taman bermain seperti apa yang mereka inginkan, adalah melalui kegiatan menggambar peta taman bermain oleh anak-anak. 


\subsection{Fase Perkembangan Anak}

Perkembangan pada anak terdiri dari beberapa fase, dimana kebutuhan tiap fasenya memiliki perbedaan. Kebutuhan yang berbeda disetiap fase inilah yang harus mampu diwadahi, sehingga dapat mendorong perkembangan anak.

Berdasarkan Yusuf (2000) dan Zulkifli (1986) usia anak dibedakan menjadi tiga fase antara lain fase sekolah (usia 05 tahun), fase masa sekolah (6-12 tahun) dan fase remaja (13-18 tahun). Berdasarkan Abu Ahmadi (1997) dalam Yusuf (2000), terdapat beberapa permainan anak antara lain permainan gerak, permainan fiksi, permainan reseptif, permainan konstruktif dan permainan konstruktif.

Tabel l Penggolongan jenis permainan

\begin{tabular}{|c|c|c|}
\hline \\
\hline $\begin{array}{c}\text { Usia Pra } \\
\text { Sekolah (0- } \\
5 \text { tahun) }\end{array}$ & $\begin{array}{c}\text { Usia } \\
\text { sekolah (6- } \\
12 \text { tahun) }\end{array}$ & $\begin{array}{l}\text { Usia remaja } \\
\quad(13-18)\end{array}$ \\
\hline $\begin{array}{l}\text { Terdapat } \\
\text { fasilitas } \\
\text { bermain } \\
\text { yang } \\
\text { mendukung } \\
\text { permainan : } \\
\text {-Permainan } \\
\text { Gerak } \\
\text {-Permainan } \\
\text { Fiksi } \\
\text {-Permainan } \\
\text { Reseptif } \\
\text {-Permainan } \\
\text { Konstruktif }\end{array}$ & $\begin{array}{l}\text { Terdapat } \\
\text { fasilitas } \\
\text { bermain } \\
\text { yang } \\
\text { mendukung } \\
\text { permainan : } \\
\text {-Permainan } \\
\text { Gerak } \\
\text {-Permainan } \\
\text { Fiksi } \\
\text {-Permainan } \\
\text { Konstruktif } \\
\text {-Permainan } \\
\text { Preatasi }\end{array}$ & $\begin{array}{l}\text { Terdapat } \\
\text { fasilitas } \\
\text { bermain } \\
\text { yang } \\
\text { mendukung } \\
: \\
\text { - Permainan } \\
\quad \text { Prestasi }\end{array}$ \\
\hline \multicolumn{3}{|c|}{$\begin{array}{c}\text { Sumber : Abu Ahmadi, } 1997 \text { dalam Yusuf } \\
\text { 2000; Zulkifli, 1986; Hurlock, } 1999 \text { dalam } \\
\text { smail, 2006; Piaget, } 1962 \text { dalam Ismail, } 2006 \\
\text { dan Vandenburg et al, } 1983 \text { dalam Ismail, } \\
2006\end{array}$} \\
\hline
\end{tabular}

\subsection{Komponen Pendukung Aktivitas Bermain Berdasarkan Usia Anak}

Menurut Barlett (2002) terdapat komponen yang mendukung anak-anak melakukan aktivitas bermain. Komponen tersebut dibedakan berdasarkan usia anak.
Tabel 2 Komponen pendukung aktivitas bermain anak

\begin{tabular}{|l|l|}
\hline \multicolumn{1}{|c|}{$\begin{array}{c}\text { Usia } \\
\text { anak }\end{array}$} & \multicolumn{1}{|c|}{ Hak anak } \\
\hline Anak \\
masih \\
kecil & - Lokasi bermain masih \\
& berada disekitar rumah \\
& $\begin{array}{l}\text { Keamanan lokasi bermain } \\
\text { - Tidak memerlukan } \\
\text { permainan dengan desain } \\
\text { khusus }\end{array}$ \\
\hline Anak & - Keamanan dan kenyamanan \\
mulai & tempat bermain \\
tumbuh & - Kemudahan menjangkau \\
& ruang publik, seperti taman, \\
& taman bermain, ruang \\
& terbuka \\
& - Alat bermain yang \\
& berorientasi proses dan \\
& fleksibel \\
\hline Anak & - Transportasi yang \\
remaja & menjangkau taman \\
& - Jika taman berada di jalan \\
& raya maka harus dilengkapi \\
& dengan adanya trotoar atau \\
& jalur pejalan kaki, jalur \\
& penyebrangan, pelican \\
& crossing dan penerangan \\
& jalan \\
& - Fasilitas bermain yang \\
& mengurangi vandalisme \\
& dan kenakalan remaja \\
& - Fasilitas berkumpul pada \\
& ruang publik \\
& - Ketentuan yang mewadai \\
& Sumber : Barlett, 2002 \\
\hline
\end{tabular}

\subsection{Taman Kota Berdasarkan Konsep Kota Layak Anak}

Taman kota berdasarkan konsep kota layak anak adalah taman kota yang menerapkan prinsip-prinsip kota layak anak dalam menjalankan fungsinya. Untuk menentukan taman kota berdasarkan konsep kota layak anak dilakukan persilangan teori antara taman kota dengan konsep kota layak anak. Komponen taman kota yang harus sesuai dengan konsep kota layak anak meliputi aksesibilitas, sarana rekreatif, sarana olahraga, fasilitas pendukung dan vegetasi. Selanjutnya setiap komponen ditentukan indikator berdasar teori. 
Dalam memenuhi kriteria taman kota harus dapat dijangkau oleh seluruh anak di Kota Surakarta. Sebagai sarana rekreatif taman kota harus mengoptimalkan fungsinya sebagai ruang rekreatif dan sosialbagi anak. Taman kota sebagai sarana olahraga harus mampu memenuhi kebutuhan anak untuk berolahraga dan beraktivitas aktif melalui penyediaan fasilitas olahraga.

Untuk mewujudkan taman kota berdasarkan konsep kota layak anak penyediaan fasilitas pendukung dan vegetasi menjadi faktor yang penting. Dengan fasilitas yang lengkap taman dapat menjadi ruang bermain yang aman dan nyaman bagi anak. Manfaat keberadaan vegetasi adalah taman menjadi tempat yang sejuk dan teduh sehingga anak-anak dapat dengan nyaman berada di taman.

\section{METODE PENELITIAN}

Penelitian ini bertujuan untuk mengetahui kesesuaian taman kota di
Surakarta berdasarkan konsep kota layak anak, dengan sasaran penelitian sebagai berikut:

- Mengidentifikasi kesesuaian komponen taman kota di Surakarta terhadap kriteria taman kota berdasarkan konsep kota layak anak

- Menganalisis kesesuaian komponen taman kota di Surakarta terhadap kriteria taman kota berdasarkan konsep kota layak anak

- Menganalisis kesesuaian taman kota di Surakarta terhadap kriteria taman kota berdasarkan konsep kota layak anak

\subsection{Variabel Penelitian}

Variabel dalam penelitian ini terdiri dari aksesibilitas, sarana rekreatif, sarana olahraga, fasilitas pendukung dan vegetasi. Berikut adalah tabel variabel, subvariabel dan indikator penelitian

Tabel 3 Variabel, Subvariabel, Indikator Penelitian Kesesuaian Taman Kota di Surakarta Berdasarkan Konsep Kota Layak Anak

\begin{tabular}{|c|c|c|c|}
\hline \multirow{2}{*}{$\begin{array}{c}\text { Variabel } \\
\text { Aksesibiilitas }\end{array}$} & Subvariabel & Indikator taman kota layak anak & Sumber \\
\hline & $\begin{array}{l}\text { Kemudahan } \\
\text { untuk } \\
\text { menjangkau } \\
\text { taman }\end{array}$ & $\begin{array}{l}\text { Terjangkau oleh transportasi umum yang } \\
\text { melayani seluruh bagian kota dengan jarak } \\
\text { maksimal } 400 \mathrm{~m} \text { dari taman }\end{array}$ & $\begin{array}{l}\text { - Whyte (1988) } \\
\text { dalam } \\
\text { Carmona } \\
\text { (2003) } \\
\text { - Barlett (2002) }\end{array}$ \\
\hline & $\begin{array}{l}\text { Jalan yang } \\
\text { ramah anak }\end{array}$ & $\begin{array}{l}\text { Ketersediaan jalur pejalan kaki menuju ke } \\
\text { taman yang bersifat kontinyu dengan } \\
\text { kriteria: } \\
\text {-Jalan Arteri dan Kolektor harus memiliki } \\
\text { jalur pejalan kaki pada jenis penggunaan } \\
\text { lahan permukiman, perkantoran, industry, } \\
\text { sekolah, terminal, perdagangan } \\
\text {-Jalan Kolektor harus memiliki jalur pejalan } \\
\text { kaki pada jenis penggunaan lahan } \\
\text { permukiman, perkantoran, industry, } \\
\text { sekolah, terminal, perdagangan } \\
\text {-Jalan Lokal dan Lingkungan harus memiliki } \\
\text { jalur pejalan kaki pada jenis penggunaan } \\
\text { lahan permukiman, perkantoran, industry, } \\
\text { sekolah, terminal, perdagangan dan tidak } \\
\text { diwajibkan jika pada penggunaan lahan } \\
\text { permukiman }\end{array}$ & $\begin{array}{l}\text { - Barlett } \\
\text { (2002) } \\
\text { - Permen PU } \\
\text { 03/PRT/M/ } \\
2014\end{array}$ \\
\hline
\end{tabular}




\begin{tabular}{|c|c|c|c|}
\hline Variabel & Sub Variabel & Indikator taman kota layak anak & Sumber \\
\hline & & $\begin{array}{l}\text { Ketersediaan lampu penerangan dengan } \\
\text { jarak maksimal } 10 \mathrm{~m}\end{array}$ & \\
\hline Aksesibilitas & & $\begin{array}{l}\text { Ketersediaan jalur penyebrangan pada } \\
\text { jalan yang memiliki lalu lintas kendaraan } \\
\text { padat, dimana jalan tersebut menjadi akses } \\
\text { masuk ke taman, dengan kriteria } \\
\text { - Jalan Arteri dan Kolektor (kecepatan }>40 \\
\text { km/jam) menggunakan penyebrangan } \\
\text { jenis pelikan } \\
\text { - Jalan Lokal dan Lingkungan (kecepatan } \\
<20 \mathrm{~km} / \text { jam) menggunakan } \\
\text { penyebrangan jenis zebra cross }\end{array}$ & \\
\hline \multirow[t]{11}{*}{$\begin{array}{l}\text { Sarana } \\
\text { rekreatif }\end{array}$} & \multirow[t]{4}{*}{$\begin{array}{l}\text { Fasilitas } \\
\text { bermain }\end{array}$} & $\begin{array}{l}\text { Ketersediaan Fasilitas bermain permainan } \\
\text { gerak }\end{array}$ & \multirow{4}{*}{$\begin{array}{l}\text { - Permen PU } \\
\text { No } \\
\text { 05/PRT/M/ } \\
2008 \\
\text { - Abu } \\
\text { Ahmadi } \\
\text { (1997) } \\
\text { dalam } \\
\text { Yusuf } \\
\text { (2000) }\end{array}$} \\
\hline & & $\begin{array}{l}\text { Ketersediaan Fasilitas bermain permainan } \\
\text { fiksi }\end{array}$ & \\
\hline & & $\begin{array}{l}\text { Ketersediaan Fasilitas bermain permainan } \\
\text { reseptif }\end{array}$ & \\
\hline & & $\begin{array}{l}\text { Ketersediaan Fasilitas bermain permainan } \\
\text { konstruktif }\end{array}$ & \\
\hline & \multirow[t]{2}{*}{$\begin{array}{l}\text { Fasilitas } \\
\text { berkumpul }\end{array}$} & $\begin{array}{l}\text { Tersedia tempat untuk berkumpul, dapat } \\
\text { berupa plasa, bangku ataupun sitting group }\end{array}$ & \multirow{2}{*}{$\begin{array}{l}\text { - Barlett } \\
(2002) \\
\text { - Siregar } \\
(2015) \\
\text { - Kustianingr } \\
\text { um et al } \\
\text { (2013) }\end{array}$} \\
\hline & & $\begin{array}{l}\text { Tempat berkumpul selalu mendapatkan } \\
\text { pencahayaan yang cukup, terutama ketika } \\
\text { malam hari }\end{array}$ & \\
\hline & $\begin{array}{l}\text { Pertimbangan } \\
\text { pendapat } \\
\text { anak dalam } \\
\text { penentuan } \\
\text { fasilitas } \\
\text { bermain }\end{array}$ & $\begin{array}{l}\text { Anak dilibatkan dalam penentuan fasilitas } \\
\text { bermain yang cocok berada di taman } \\
\text { melalui penggalian pendapat, lalu } \\
\text { pendapatnya dipertimbangkan dalam } \\
\text { perencanaan taman }\end{array}$ & $\begin{array}{l}\text { Omid et al } \\
(2007)\end{array}$ \\
\hline & $\begin{array}{l}\text { Taman } \\
\text { sebagai } \\
\text { tempat event } \\
\text { sosial budaya } \\
\text { anak }\end{array}$ & $\begin{array}{l}\text { Taman digunakan sebagai tempat } \\
\text { pelaksanaan event sosial dan budaya } \\
\text { terkait anak-anak }\end{array}$ & $\begin{array}{l}\text { Hart et al } \\
(2011)\end{array}$ \\
\hline & \multirow{3}{*}{$\begin{array}{l}\text { Keamanan } \\
\text { dan } \\
\text { Kenyamanan } \\
\text { Taman }\end{array}$} & $\begin{array}{l}\text { Keberadaan petugas keamanan yang } \\
\text { memastikan taman aman untuk beraktivitas }\end{array}$ & \multirow[t]{3}{*}{ Barlett (2002) } \\
\hline & & $\begin{array}{l}\text { Saluran drainase yang berada di taman } \\
\text { merupakan saluran drainase tertutup, } \\
\text { sehingga aman bagi anak }\end{array}$ & \\
\hline & & $\begin{array}{l}\text { Keberadaan petugas kebersihan yang } \\
\text { menjaga kebersihan taman sehingga } \\
\text { berbas dari sampah }\end{array}$ & \\
\hline
\end{tabular}




\begin{tabular}{|c|c|c|c|}
\hline Variabel & Sub Variabel & Indikator taman kota layak anak & Sumber \\
\hline $\begin{array}{l}\text { Sarana } \\
\text { olahraga }\end{array}$ & $\begin{array}{l}\text { Fasilitas } \\
\text { olahraga }\end{array}$ & $\begin{array}{l}\text { Ketersediaan fasilitas olahraga berupa } \\
\text { lapangan yang dapat digunakan untuk } \\
\text { permainan berkelompok }\end{array}$ & 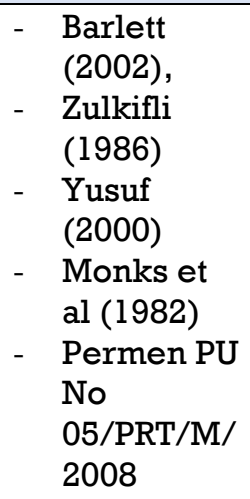 \\
\hline \multirow[t]{9}{*}{$\begin{array}{l}\text { Fasilitas } \\
\text { pendukung }\end{array}$} & \multirow{8}{*}{$\begin{array}{l}\text { Ketersediaan } \\
\text { fasilitas } \\
\text { pendukung } \\
\text { yang ramah } \\
\text { terhadap } \\
\text { penyandang } \\
\text { disabilitas }\end{array}$} & Tersedia tempat parkir di taman & \multirow{8}{*}{$\begin{array}{l}\text { - Permen PU } \\
\text { No } \\
\text { 05/PRT/M/ } \\
2008 \\
\text { - Widyawati } \\
\text { et al } \\
\text { (2015) } \\
\text { - Kustianingr } \\
\text { um et al } \\
\text { (2013) }\end{array}$} \\
\hline & & $\begin{array}{l}\text { Tersedia tempat parkir bagi penyandang } \\
\text { disabilitas di taman kota }\end{array}$ & \\
\hline & & $\begin{array}{l}\text { Tersedia jalur pejalan kaki yang yang } \\
\text { bersifat kontinue keseluruh bagian taman, } \\
\text { sehingga dapat menghubungkan setiap } \\
\text { bagian fungsi taman }\end{array}$ & \\
\hline & & $\begin{array}{l}\text { Tersedia pegangan khusus bagi anak-anak } \\
\text { dan penyandang disabilitas pada spot } \\
\text { perbedaan ketinggian lantai }\end{array}$ & \\
\hline & & $\begin{array}{l}\text { Tersedia ramp pada jalur sirkulasi bagi } \\
\text { orang yang tidak dapat menggunakan } \\
\text { tangga yang dilengkapi dengan pegangan } \\
\text { rambat }\end{array}$ & \\
\hline & & Tersedia tempat sampah & \\
\hline & & $\begin{array}{l}\text { Tersedia tempat sampah pada fasilitas } \\
\text { berkumpul }\end{array}$ & \\
\hline & & $\begin{array}{l}\text { Tempat sampah dibedakan menjadi } 2 \text { jenis } \\
\text { yaitu organik dan nonorganik }\end{array}$ & \\
\hline & $\begin{array}{l}\text { Pertimbangan } \\
\text { pendapat } \\
\text { anak dalam } \\
\text { penentuan } \\
\text { fasilitas } \\
\text { pendukung } \\
\text { yang } \\
\text { diperlukan di } \\
\text { taman }\end{array}$ & $\begin{array}{l}\text { Anak dilibatkan dalam penentuan fasilitas } \\
\text { apa saja yang sebaiknya ada di taman } \\
\text { melalui penggalian pedapat lalu } \\
\text { pendapatnya dipertimbangkan dalam } \\
\text { perencanaan taman }\end{array}$ & $\begin{array}{l}\text { Omid et al } \\
(2007)\end{array}$ \\
\hline
\end{tabular}




\begin{tabular}{|c|c|c|c|}
\hline Variabel & Sub Variabel & Indikator taman kota layak anak & Sumber \\
\hline & \multirow[t]{3}{*}{$\begin{array}{l}\text { Ketersediaan fasilitas } \\
\text { air bersih }\end{array}$} & $\begin{array}{l}\text { Adanya fasilitas air bersih yang } \\
\text { dapat digunakan oleh pengunjung }\end{array}$ & $\begin{array}{l}\text { - Hart et al } \\
(2011)\end{array}$ \\
\hline & & $\begin{array}{l}\text { Adanya fasilitas air bersih yang } \\
\text { dapat digunakan oleh pengunjung }\end{array}$ & $\begin{array}{l}\text { - Hart et al } \\
(2011)\end{array}$ \\
\hline & & $\begin{array}{l}\text { Adanya fasilitas air minum yang } \\
\text { dapat dimanfaatkan oleh } \\
\text { pengunjung }\end{array}$ & $\begin{array}{l}\text { - Glesson et al } \\
\text { (2006) } \\
\text { - Siregar (2015) }\end{array}$ \\
\hline & \multirow{4}{*}{$\begin{array}{l}\text { Ketersediaan fasilitas } \\
\text { sanitasi }\end{array}$} & Tersedia toilet yang berfungsi & \multirow{4}{*}{$\begin{array}{l}\text { - Glesson et al } \\
\text { (2006) } \\
\text { - Widyawati et } \\
\text { al (2015) } \\
\text { - Wolcock et al } \\
\text { (2008) }\end{array}$} \\
\hline & & $\begin{array}{l}\text { Tersedia toilet khusus yang } \\
\text { berfungsi untuk penyandang } \\
\text { disabilitas }\end{array}$ & \\
\hline & & $\begin{array}{l}\text { Toilet dibedakan menjadi } \\
\text { perempuan dan laki-laki }\end{array}$ & \\
\hline & & Toilet bersih dan tidak bau & \\
\hline \multirow[t]{2}{*}{ Vegetasi } & $\begin{array}{l}\text { Ketersediaan vegetasi } \\
\text { di taman }\end{array}$ & $\begin{array}{l}\text { Luas area yang ditanami tanaman } \\
\text { berkisar antara 80\%-90\% dari total } \\
\text { luas taman kota }\end{array}$ & $\begin{array}{l}\text { Permen PU No } \\
\text { 05/PRT/M/2008 }\end{array}$ \\
\hline & $\begin{array}{l}\text { Pertimbangan } \\
\text { pendapat anak tentang } \\
\text { vegetasi yang } \\
\text { diperlukan pada taman } \\
\text { (seperti : pohon besar, } \\
\text { kecil atau bunga) }\end{array}$ & $\begin{array}{l}\text { Anak dilibatkan dalam penentuan } \\
\text { vegetasi yang diperlukan pada } \\
\text { taman (seperti : pohon besar, kecil } \\
\text { atau bunga), melalui penggalian } \\
\text { pendapat lalu pendapatnya } \\
\text { dipertimbangkan dalam } \\
\text { perencanaan taman }\end{array}$ & $\begin{array}{l}\text { Omid et al } \\
(2007)\end{array}$ \\
\hline
\end{tabular}

Sumber : Kompilasi Peneliti dari Berbagai Sumber, 2017

\subsection{Teknik Analisis}

Penelitian ini menggunakan teknik analisis skoring. Teknik analisis skoring dilakukan dengan cara memberikan nilai pada kondisi yang ada di lapangan berdasarkan penilaian yang telah di tentukan (Mulyana, 2005).

\subsubsection{Analisis kesesuaian komponen taman kota terhadap kriteria taman kota berdasarkan konsep kota layak anak}

Pada analisis ini dilakukan penilaian kesesuaian tiap komponen taman. Komponen taman kota terdiri dari aksesibilitas, sarana rekreatf, sarana olahraga, fasilitas pendukung danvegetasi. Penilaian dilakukan dengan memberikan nilai 1 untuk komponen yang sesuai dan nilai O untuk komponen yang tidak sesuai.
3.2.2 Analisis kesesuaian taman kota di Surakarta terhadap kriteria taman kota berdasarkan konsep kota layak anak

Penilaian kesesuaian taman kota dilakukan setelah nilai dari setiap

komponen diketahui. Klasifikasi dilakukan dengan mengkonversikan nilai kesesuaian kedalam bentuk persentase (Sugiyono, 1999).

$$
\begin{aligned}
& \text { Presentase kesesuaian }=\frac{\text { NIlai } \text { kesesuaian }}{\text { Nilai } \text { maksimal }} \\
& \mathrm{x} 100 \%
\end{aligned}
$$

Klasifikasi kesesuaiannya sebagai berikut :

a. Persentase kesesuaian termasuk dalam rentang $0-49 \%$ dinyatakan "mendekati tidak sesuai" sebagai taman kota berdasarkan konsep kota layak anak 
b. Persentase kesesuaian adalah 50\% maka kesesuaian taman kota di Surakarta dinyatakan "antara sesuai dan tidak sesuai" sebagai taman kota berdasarkan konsep kota layak anak

c. Persentase kesesuaian termasuk dalam rentang $51 \%-100 \%$ maka kesesuaian kesesuaian taman kota di Surakarta dinyatakan "mendekati sesuai" sebagai taman kota berdasarkan konsep kota layak anak

\section{HASIL DAN PEMBAHASAN}

\subsection{Kesesuaian Komponen Taman} Kota Berdasarkan Konsep Kota Layak Anak

Taman kota di Surakarta terdiri dari Taman Sekartaji, Taman Urban Forest Pucangsawit, Taman P2KH Semanggi, Taman P2KH Mojosongo dan Taman Sadinoe.

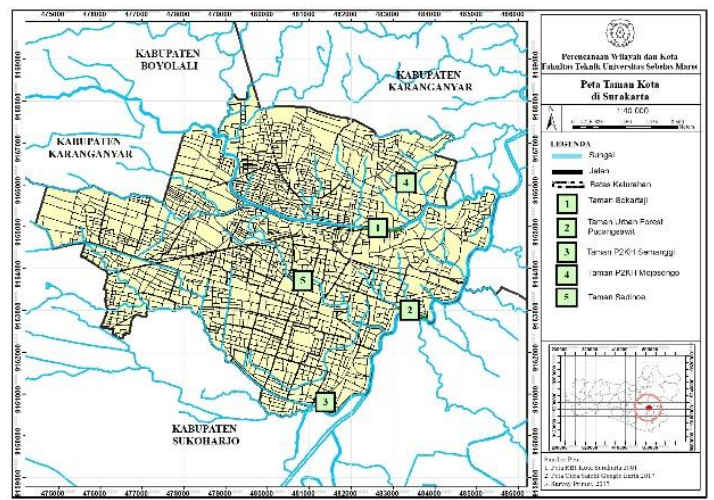

Gambar 1 Persebaran Taman Kota di Surakarta

Komponen taman kota terdiri dari aksesibilitas, sarana rekreatif, sarana olahraga, fasilitas pendukung dan vegetasi.

- Aksesibilitas

Pada penilaian kesesuaian komponen aksesibilitas, 40\% taman tidak sesuai dengan kriteria, yaitu Taman Sekartaji dan Taman Urban Forest Pucangsawit. Hal tersebut berdampak pada terjadinya kesenjangan dalam pemanfaatan taman kota dan pemenuhan kebutuhan bermain, karena tidak semua anak mendapat kesempatan yang sama untuk mengakses taman.

Tabel 4 Kesesuaian Komponen Aksesibilitas

\begin{tabular}{|l|c|c|}
\hline \multicolumn{1}{|c|}{ Taman } & $\begin{array}{c}\text { Total } \\
\text { nilai } \\
\text { Variabel }\end{array}$ & $\begin{array}{c}\text { Kesesuaian } \\
\text { Variabel }\end{array}$ \\
\hline $\begin{array}{l}\text { Taman } \\
\text { Sekartaji }\end{array}$ & $\mathbf{0 , 5 0 0}$ & $\begin{array}{c}\text { Tidak } \\
\text { sesuai }\end{array}$ \\
\hline $\begin{array}{l}\text { Taman Urban } \\
\text { Forest } \\
\text { Pucangsawit }\end{array}$ & $\mathbf{0 , 5 0 0}$ & $\begin{array}{l}\text { Tidak } \\
\text { sesuai }\end{array}$ \\
\hline $\begin{array}{l}\text { Taman P2KH } \\
\text { Semanggi }\end{array}$ & $\mathbf{0 , 8 3 4}$ & Sesuai \\
\hline $\begin{array}{l}\text { Taman P2KH } \\
\text { Mojosongo }\end{array}$ & $\mathbf{0 , 3 3 4}$ & Sesuai \\
\hline $\begin{array}{l}\text { Taman } \\
\text { Sadinoe }\end{array}$ & $\mathbf{0 , 8 3 4}$ & Sesuai \\
\hline
\end{tabular}

Sumber : Analisis Penulis, 2017

- Sarana Rekreatif

Pada penilaian kesesuaian komponen sarana rekreatif, semua taman kota tidak sesuai terhadap kriteria komponen sarana rekreatif. Hal tersebut berdampak pada tidak optimalnya pemenuhan kebutuhan anak akan aktivitas rekreatif dan kreatif.

Tabel 5 Kesesuaian Komponen Sarana Rekreatif

\begin{tabular}{|l|c|c|}
\multicolumn{1}{|c}{ Taman } & $\begin{array}{c}\text { Total } \\
\text { nilai } \\
\text { Variabel }\end{array}$ & $\begin{array}{c}\text { Kesesuaian } \\
\text { Variabel }\end{array}$ \\
\hline $\begin{array}{l}\text { Taman } \\
\text { Sekartaji }\end{array}$ & $\mathbf{0 , 2 5 0}$ & $\begin{array}{c}\text { Tidak } \\
\text { sesuai }\end{array}$ \\
\hline $\begin{array}{l}\text { Taman Urban } \\
\text { Forest } \\
\text { Pucangsawit }\end{array}$ & $\mathbf{0 , 1 5 0}$ & $\begin{array}{c}\text { Tidak } \\
\text { sesuai }\end{array}$ \\
\hline $\begin{array}{l}\text { Taman P2KH } \\
\text { Semanggi }\end{array}$ & $\mathbf{0 , 3 1 7}$ & $\begin{array}{c}\text { Tidak } \\
\text { sesuai }\end{array}$ \\
\hline $\begin{array}{l}\text { Taman P2KH } \\
\text { Mojosongo }\end{array}$ & $\mathbf{0 , 1 5 0}$ & $\begin{array}{c}\text { Tidak } \\
\text { sesuai }\end{array}$ \\
\hline $\begin{array}{l}\text { Taman } \\
\text { Sadinoe }\end{array}$ & $\mathbf{0 , 2 1 7}$ & $\begin{array}{c}\text { Tidak } \\
\text { sesuai }\end{array}$ \\
\hline
\end{tabular}

Sumber : Analisis Penulis, 2017 
- Sarana Olahraga

Pada penilaian kesesuaian komponen sarana olahraga, $80 \%$ taman kota tidak sesuai terhadap kriteria komponen sarana olahraga. Taman yang sesuai dengan kriteria hanya Taman Urban Forest Pucangsawit. Akibatnya, kebutuhan anak untuk permainan gerak dan prestasi tidak terpenuhi. Padahal olahraga adalah aktivitas penting bagi anak usia remaja dan prasekolah.

Tabel 6 Kesesuaian Komponen Sarana Olahraga

\begin{tabular}{|l|c|c|}
\hline \multicolumn{1}{|c|}{ Taman } & $\begin{array}{c}\text { Total } \\
\text { nilai } \\
\text { Variabel }\end{array}$ & $\begin{array}{c}\text { Kesesuaian } \\
\text { Variabel }\end{array}$ \\
\hline $\begin{array}{l}\text { Taman } \\
\text { Sekartaji }\end{array}$ & $\mathbf{0}$ & $\begin{array}{c}\text { Tidak } \\
\text { Sesuai }\end{array}$ \\
\hline $\begin{array}{l}\text { Taman Urban } \\
\text { Forest } \\
\text { Pucangsawit }\end{array}$ & $\mathbf{1}$ & Sesuai \\
\hline $\begin{array}{l}\text { Taman P2KH } \\
\text { Semanggi }\end{array}$ & $\mathbf{0}$ & $\begin{array}{l}\text { Tidak } \\
\text { Sesuai }\end{array}$ \\
\hline $\begin{array}{l}\text { Taman P2KH } \\
\text { Mojosongo }\end{array}$ & $\mathbf{0}$ & $\begin{array}{c}\text { Tidak } \\
\text { Sesuai }\end{array}$ \\
\hline $\begin{array}{l}\text { Taman } \\
\text { Sadinoe }\end{array}$ & $\mathbf{0}$ & $\begin{array}{c}\text { Tidak } \\
\text { Sesuai }\end{array}$ \\
\hline
\end{tabular}

Sumber : Analisis Penulis, 2017

- Fasilitas Pendukung

Pada penilaian kesesuaian fasilitas pendukung, semua taman kota di Surakarta tidak sesuai terhadap kriteria komponen fasilitas pendukung. Akibatnya semua aktivitas anak di taman kota tidak dapat optimal, karena tidak ditunjang dengan keberadaan fasilitas pendukung.

Tabel 7 Kesesuaian Komponen Fasilitas

\begin{tabular}{|l|c|c|}
\multicolumn{1}{|c|}{ Pendukung } \\
\hline Taman & $\begin{array}{c}\text { Total } \\
\text { nilai } \\
\text { Variabel }\end{array}$ & $\begin{array}{c}\text { Kesesuaian } \\
\text { Variabel }\end{array}$ \\
\hline $\begin{array}{l}\text { Taman } \\
\text { Sekartaji }\end{array}$ & $\mathbf{0 , 1 2 4}$ & $\begin{array}{c}\text { Tidak } \\
\text { Sesuai }\end{array}$ \\
\hline $\begin{array}{l}\text { Taman Urban } \\
\text { Forest } \\
\text { Pucangsawit }\end{array}$ & $\mathbf{0 , 0 9 3}$ & $\begin{array}{l}\text { Tidak } \\
\text { Sesuai }\end{array}$ \\
\hline
\end{tabular}

\begin{tabular}{|l|c|c|}
\hline \multicolumn{1}{|c|}{ Taman } & $\begin{array}{c}\text { Total } \\
\text { nilai } \\
\text { Variabel }\end{array}$ & $\begin{array}{c}\text { Kesesuaian } \\
\text { Variabel }\end{array}$ \\
\hline $\begin{array}{l}\text { Taman P2KH } \\
\text { Semanggi }\end{array}$ & $\mathbf{0 , 1 2 4}$ & $\begin{array}{c}\text { Tidak } \\
\text { Sesuai }\end{array}$ \\
\hline $\begin{array}{l}\text { Taman P2KH } \\
\text { Mojosongo }\end{array}$ & $\mathbf{0 , 0 3 1}$ & $\begin{array}{c}\text { Tidak } \\
\text { Sesuai }\end{array}$ \\
\hline $\begin{array}{l}\text { Taman } \\
\text { Sadinoe }\end{array}$ & $\mathbf{0 , 1 5 5}$ & $\begin{array}{c}\text { Tidak } \\
\text { Sesuai }\end{array}$ \\
\hline
\end{tabular}

Sumber : Analisis Penulis, 2017

- Vegetasi

Pada penilaian kesesuaian komponen vegetasi, semua taman kota tidak sesuai terhadap kriteria komponen vegetasi. Akibatnya, hak anak untuk mendapatkan ruang hijau sebagai tempat bermain dan berkumpul tidak terpenuhi secara optimal.

Tabel 8 Kesesuaian Komponen Vegetasi

\begin{tabular}{|l|c|c|}
\hline \multicolumn{1}{|c|}{ Taman } & $\begin{array}{c}\text { Total } \\
\text { nilai } \\
\text { Variabel }\end{array}$ & $\begin{array}{c}\text { Kesesuaian } \\
\text { Variabel }\end{array}$ \\
\hline $\begin{array}{l}\text { Taman } \\
\text { Sekartaji }\end{array}$ & $\mathbf{0 , 5 0 0}$ & $\begin{array}{c}\text { Tidak } \\
\text { Sesuai }\end{array}$ \\
\hline $\begin{array}{l}\text { Taman Urban } \\
\text { Forest } \\
\text { Pucangsawit }\end{array}$ & $\mathbf{0 , 5 0 0}$ & $\begin{array}{l}\text { Tidak } \\
\text { Sesuai }\end{array}$ \\
\hline $\begin{array}{l}\text { Taman P2KH } \\
\text { Semanggi }\end{array}$ & $\mathbf{0 , 5 0 0}$ & $\begin{array}{l}\text { Tidak } \\
\text { Sesuai }\end{array}$ \\
\hline $\begin{array}{l}\text { Taman P2KH } \\
\text { Mojosongo }\end{array}$ & $\mathbf{0 , 5 0 0}$ & $\begin{array}{l}\text { Tidak } \\
\text { Sesuai }\end{array}$ \\
\hline $\begin{array}{l}\text { Taman } \\
\text { Sadinoe }\end{array}$ & $\mathbf{0}$ & $\begin{array}{c}\text { Tidak } \\
\text { Sesuai }\end{array}$ \\
\hline
\end{tabular}

Sumber : Analisis Penulis, 2017

\subsection{Kesesuaian Taman Kota di Surakarta Berdasarkan Konsep Kota Layak Anak}

Penilaian ini dilakukan untuk mengetahui kesesuaian setiap taman di Kota Surakarta terhadap taman kota berdasarkan konsep kota layak anak.

Tabel 9 Kesesuaian Taman Kota

Berdasarkan Konsep Kota Layak Anak

\begin{tabular}{|l|l|l|}
\hline \multicolumn{1}{|c|}{ Taman } & $\begin{array}{c}\text { Total } \\
\text { nilai } \\
\text { Variabel }\end{array}$ & $\begin{array}{c}\text { Kesesuaian } \\
\text { Variabel }\end{array}$ \\
\hline $\begin{array}{l}\text { Taman } \\
\text { Sekartaji }\end{array}$ & $27 \%$ & $\begin{array}{l}\text { Mendekati } \\
\text { tidak } \\
\text { sesuai }\end{array}$ \\
\hline
\end{tabular}




\begin{tabular}{|l|l|l|}
\hline \multicolumn{1}{|c|}{ Taman } & \multicolumn{1}{|c|}{$\begin{array}{c}\text { Total } \\
\text { nilai } \\
\text { Variabel }\end{array}$} & $\begin{array}{l}\text { Kesesuaian } \\
\text { Variabel }\end{array}$ \\
\hline $\begin{array}{l}\text { Taman Urban } \\
\text { Forest } \\
\text { Pucangsawit }\end{array}$ & $45 \%$ & $\begin{array}{l}\text { Mendekati } \\
\text { tidak } \\
\text { sesuai }\end{array}$ \\
\hline $\begin{array}{l}\text { Taman P2KH } \\
\text { Semanggi }\end{array}$ & $36 \%$ & $\begin{array}{l}\text { Mendekati } \\
\text { tidak } \\
\text { sesuai }\end{array}$ \\
\hline $\begin{array}{l}\text { Taman P2KH } \\
\text { Mojosongo }\end{array}$ & $20 \%$ & $\begin{array}{l}\text { Mendekati } \\
\text { tidak } \\
\text { sesuai }\end{array}$ \\
\hline $\begin{array}{l}\text { Taman } \\
\text { Sadinoe }\end{array}$ & $24 \%$ & $\begin{array}{l}\text { Mendekati } \\
\text { tidak } \\
\text { sesuai }\end{array}$ \\
\hline
\end{tabular}

Sumber : Analisis Penulis, 2017

Berdasarkan hasil penilaian diketahui bahwa kesesuaian seluruh taman kota di Surakarta berdasarkan konsep kota layak anak adalah mendekati tidak sesuai. Hal tersebut dikarenakan persentase kesesuaian taman kota berkisar antara 0-49\%, dengan urutan taman dari paling yang mendekati tidak sesuai adalah Taman P2KH Mojosongo, Taman Sadinoe, Taman P2KH Sekartaji, Taman P2KH Semanggi, Taman Urban Forest Pucangsawit. Dengan demikian dapat disimpulkan bahwa taman kota di Surakarta "mendekati tidak sesuai" terhadap kriteria taman kota berdasarkan konsep kota layak anak.

Akibat dari taman kota yang mendekati tidak sesuai terhadap kriteria taman kota berdasarkan konsep kota layak anak adalah tidak terpenuhinya hak anak untuk mendapatkan ruang bermain hijau yang nyaman dan aman untuk aktivitas bermain segala usia anak. Dampaknya adalah pemenuhan kebutuhan anak untuk bermain menjadi tidak optimal.

Aktivitas bermain anak yang kurang optimal akan berdampak pada perkembangan anak meliputi perkembangan sosial, emosional dan kognitif. Padahal anak merupakan salah satu penerus bangsa yang seharusnya dipenuhi kebutuhannya untuk mengoptimalkan perkembangan.

\section{KESIMPULAN}

Kesimpulan yang didapatkan baik selama penelitian berlangsung ataupun hasil dari penelitian serta saran-saran, baik untuk hasil penelitian serta penelitian selanjutnya adalah sebagai berikut.

\subsection{Kesimpulan}

Penelitian kesesuaian taman kota di Surakarta berdasarkan konsep kota layak anak ini selama proses penelitian dan berdasarkan analisis menemukan banyak hal dan dapat ditarik beberapa kesimpulan sebagai berikut :

a. Kesesuaian komponen aksesibilitas yang ditinjau dari kemudahan menjangkau taman dan jalan yang ramah anak adalah berdasarkan hasil penelitian adalah $40 \%$ taman kota di Surakarta tidak sesuai dengan kriteria. Taman yang tidak memenuhi kriteria adalah Taman Sekartaji dan Taman Urban Forest Pucangsawit, sedangkan taman yang sesuai kriteria adalah Taman P2KH Semanggi, P2KH Mojosongo dan Taman Sadinoe.

b. Kesesuaian komponen sarana rekreatif yang ditinjau dari fasilitas bermain, fasilitas berkumpul, pertimbangan pendapat anak untuk fasilitas bermain, taman sebagai tempat event sosial dan budaya serta keamanan dan kenyamanan taman adalah semua taman kota di Surakarta tidak sesuai terhadap kriteria komponen sarana rekreatif.

c. Kesesuaian komponen sarana olahraga yang ditinjau dari ketersediaan fasilitas olahraga berupa lapangan olahraga untuk permainan kelompok adalah $80 \%$ taman kota di Surakarta tidak sesuai terhadap kriteria sarana olahraga. Taman yang memiliki fasilitas 
olahrga hanyalah Taman Urban Forest Pucangsawit.

d. Kesesuaian komponen fasilitas pendukung yang ditinjau dari fasilitas pendukung yang ramah disabilitas, pertimbangan pendapat anak dalam penentuan fasilitas pendukung, ketersediaan fasilitas air bersih dan ketersediaan fasilitas sanitas adalah semua taman kota di Surakarta tidak sesuai terhadap kriteria.

e. Kesesuaian komponen vegetasi yang ditinjau dari ketersediaan vegetasi di taman dan pertimbangan pendapat anak terkait vegetasi yang diperlukan di taman adalah semua taman kota di Surakarta tidak sesuai terhadap kriteria.

f. Kesesuaian taman kota berdasarkan konsep kota layak anak yang ditinjau dari komponen taman kota berdasarkan konsep kota layak anak meliputi komponen aksesibilitas, sarana rekreatif, sarana olahraga, fasilitas pendukung dan vegetasi adalah semua taman kota di Surakarta "mendekati tidak sesuai".

\subsection{Saran}

Saran yang dapat peneliti sampaikan setelah melakukan proses penelitian antara lain sebagai berikut :

a. Perlu adanya peningkatan aksesibilitas menuju taman, melalui penambahan jalur pejalan kaki menuju taman dan jalur penyebrangan sesuai dengan jenis jalan. Selain itu perlu adanya perluasan trayek angkot untuk memberi kesempatan yang sama pada anak untuk menuju taman kota.

b. Perlu adanya perbaikan dan peningkatan terhadap komponen sarana rekreatif meliputi fasilitas bermain dan fasilitas berkumpul, serta perlu adanya peningkatan keamanan dan kenyamanan taman dengan penambahan petugas kebersihan dan keamanan. Dalam penentuan fasilitas bermain ini juga harus mempertimbangkan pendapat anak. Taman kota juga harus digunakan sebagai tempat event sosial dan budaya yang melibatkan anak.

c. Perlu adanya penambahan fasilitas olahraga berupa lapangan olahraga terbuka pada taman-taman yang belum memiliki lapangan olahraga, sehingga kebutuhan akan aktivitas olahraga anak dapat terpenuhi.

d. Perlu adanya peningkatan kualitas dan kuantitas fasilitas pendukung pada taman kota di Surakarta, terutama fasilitas untuk penyandang disabilitas.

e. Pada taman kota yang belum memenuhi kriteria ketersediaan vegetasi harus ditambahkan vegetasi. Selain itu, dalam penentuan vegetasi yang diperlukan di taman harus mempertimbangkan pendapat anak.

f. Untuk penelitian selanjutnya, dapat meneliti kesesuaian taman kota di Surakarta berdasarkan konsep kota layak anak ditinjau dari persepsi orang tua atau anak-anak.

\section{REFERENSI}

BAPERMAS. 2013. Profil Anak Kota Surakarta. Surakarta : BAPERMAS

Barlett, Sheriden. 2002. Children's Rights and the Physical Environment - a Review of Current Knowledge. Sweden : Save the Children Sweden

Carmona, Matthew. Tim Heath. Taner OC. Sreve Tiesdell. 2003. Public Space Urban Space. Architectural Press : UK

Glesson, Brendan. Neil Sipe. 2006. Creating Child Friendly Cities : Reinstating Kids in The City. Routledge : USA

Hart, Roger. Pamela Wridt. 2011. The Child Friendly Community Assessment 
Tools A Facilitator's Guide to Local Assessment of Children's Right. New York University : USA

Ismail. 2006. Education Game. Yogyakarta: Pilar Media

Joga, Nirwono. 2013. Gerakan Kota Hijau. Jakarta : PT Gramedia Pustaka Utama

Kustianingrum, Dwi. Angga Kusumah Sukarya. Rifan Athariq Nugraha. Franderdi Rachadi Tyagarga. 2013. Fungsi dan Aktifitas Taman Ganesha sebagi Ruang Publik di Kota Bandung. Reka Karsa. No. 2. Vol. 1

Monks, F.J, AMF, Knoers. Sri Rahayu Haditono. $1982 . \quad$ Psikologi Perkembangan : Pengantar dalam Berbagai Bagiannya. Jogyakarta : UGM Press

Mulyana, Rosgandika. 2005. Metode Penelitian. Bandung : Alfabeta

Omid, Rismanchian \& Amin Rismanchian. Children Participation in Planning Processes : The Case of Child Friendly City Project in PostEarthquake Bam, Iran. Urban Design International 12, 143-154. 2007

Peraturan Menteri PP dan PA Nomor 12 tahun 2011 tentang Indikator Kabupaten/Kota Layak Anak

Peraturan Menteri PU Nomor 03/PRT/M/2014 tentang Pedoman Perencanaan, Penyediaan, Dan Pemanfaatan Prasarana Dan Sarana Jaringan Pejalan Kaki Di Kawasan Perkotaan

Peraturan Menteri PU Nomor 05/PRT/M/2008 tentang Pedoman Penyediaan dan Pemanfaatan RTH di Kawasan Perkotaan

Riggio, Eliana. 2002. Child Friendly rities : Good Governance in The Best

205 srest of The Child. Environment and Urbanization, Vol. 14, No. 2, October 2002

Siregar, Hari H. 2015. Tingkat Kenyamanan Taman Kota sebagai Ruang Interaksi Masyarakat Perkotaan. Temu Ilmiah IPLBI
Subiyakto, Rudi. 2012. Membangun Kota Layak Anak: Studi Kebijakan Publik di Era Otonomi Daerah. Sosio Religia, Vol. 10, No.1, Februari 2012 Sugiyono.1999. Metode Penelitian Bisnis. Alfabeta : Bandung

UNICEF. 2004. Building Child Friendly Cities, A Fraework for Action. UNICEF Innocenti Research Centre. <www.childfrinedlycities.org/pdf/ cfc_booklet_eng.pdf> [27 September 2016]

UNICEF . 2016. What is a Child Friendly City?.<http://childfriendlycities.or g/ overview/ what-is-a-childfriendly-city/\# $>\quad[27$ September 2016]

Veitch, J., Salmon, J., \& Ball, K. (2007). Children 's Geographies Children's Perceptions of the Use of Public Open Spaces for Active Free- play, 5.

Widyawati, Karya. Penilaian Ruang Bermain Anak di Kota Depok sebagai Salah Satu Indikator Tercapainya Kota Layak Anak. Faktor Exacta 8 (3) : 195-207, 2015

Wolcock, Geoff. Wendy Steels . 2008. Child Friendly Community Indicators-Literature Review. Griffith University : Queensland

Yusuf. 2000. Psikologi Anak. PT Suka Buka : Jakarta Selatan

Zulkifli. 1986. Psikologi Perkembangan. Remadja Karya : Bandung. 
